\title{
New Dimensions of Understanding of Lifelong Learning from Antiquity to Comenius
}

\author{
Tadej Vidmar ${ }^{1}$ \\ ${ }^{1}$ Department of Educational Sciences, Faculty of Arts, University of Ljubljana, Ljubljana, Slovenia \\ Correspondence: Tadej Vidmar, Filozofska fakulteta, Univerza v Ljubljani, Aškerčeva 2, 1000 Ljubljana, \\ Slovenia. E-mail: tadej.vidmar@ff.uni-lj.si
}

Received: July 28, 2014

Accepted: August 25, 2014 Online Published: August 25, 2014

doi:10.5539/res.v6n3p91

URL: http://dx.doi.org/10.5539/res.v6n3p91

\begin{abstract}
Modern concept of lifelong learning has two components, namely increasing of employability, which means professional development and active citizenship. The problem is lack of development of personality. Both functions of modern theory of lifelong learning were already known in the history and therefore the concept in the broadest sense is not the idea of contemporaneity. Already in the ancient Greece and Rome, the meaning of education and learning after concluded course of formal schooling was emphasized. Even in the Middle Ages both primary components of lifelong learning were frequently mentioned and demanded. J. A. Comenius was the first one, who directly founded the need for learning during entire life and who also made a kind of concept of such education or learning.
\end{abstract}

Keywords: lifelong learning, Comenius, personal development, professional development, active citizenship, informal learning, Pampaedia, permanent education, Middle Ages, Ancient Greece

\section{Introduction}

In the second half of the 20th century and early 21 st century, the concept of lifelong learning, that is learning or education that takes place not only in the early years, but throughout the entire lifetime of an individual, spread rapidly and gained in importance. According to this concept, individuals should learn and acquire new knowledge even after the conclusion of their formal education, regardless of their achieved level of education. Therefore, they should be encouraged to acquire and increase their knowledge, skills, and aptitudes even later in their life, in fact, to the end of life (Delors, 1996; Establishing an integrated action programme in the field of lifelong learning: Decision of the European parliament and of the council, 2004; A memorandum on lifelong learning, 2000; Policy brief: Lifelong learning, 2001). This shift from "education" to "learning" perhaps reflects a growing interest in learning, even if it is unorganized and episodic, entirely experiential, and even if it does not take place in the institutions of education. This concept of education became known as the concept of lifelong education and later lifelong learning (Smith, 2001).

When we speak about lifelong learning, we are thinking, as a rule, of the modern notion and perception, and believe that lifelong learning is a contemporary invention. Such a conviction is only partly correct, because particular elements of modern understanding of lifelong learning can be identified in almost every historical period.

In the following sections, we will first analyze the modern understanding and concept of lifelong learning and then identify particular elements or dimensions of lifelong learning in ancient Greece and Rome, in the Middle Ages and in the work of J. A. Comenius, who was one of the first pedagogues in history who systematically elaborated the concept of lifelong learning and also one of the founders of the modern concept of lifelong learning.

\section{The Concept of Lifelong Education/Learning}

Before the 20th century, neither theorists nor practitioners were very interested in generating a coherent model of adult learning, of how adults acquire new knowledge. The most important issue for them, which depended on social conditions, was primarily: how to educate children and youth and to what level, how to provide them with basic knowledge, etc. To be preoccupied with questions about the acquisition of knowledge and comprehension of adults was an important topic only for singular pedagogues, who also had their own particular agenda (i.e., 
goals and intentions) concerning these issues. Above all, in relation to the concept that even adults should acquire new knowledge and skills, the emphasis was on individuals who had already been formally educated, which means that the goal was not basic literacy.

In 1994 The European Lifelong Learning Initiative (ELLI) organized its first global conference on lifelong learning in Rome. As a result, lifelong learning was defined as "a continually supportive process, which stimulates and empowers individuals to acquire all the knowledge, values, skills and understanding they will require throughout their lifetimes and to apply them with confidence, creativity and enjoyment in all roles, circumstances, and environments" (Watterston, 2006).

The growing demand for learning which would last throughout an individual's life was in a way globalized by UNESCO, which in the mid-90s of the 20th century, defined basic global directions for the development of lifelong learning. UNESCO used the term "permanent education", which was later replaced by the term "lifelong learning". The intent of the term was already suited to the recent understanding of lifelong learning, which should open new possibilities for learning for everyone and for different purposes, and which would give adults a second or even third chance to satisfy their desire for knowledge, beauty or outmatch themselves (Delors, 1996, p. 103).

On this basis the four "pillars" on which the concept of lifelong education/learning needs to be established and developed were defined (Delors, 1996, pp. 78-89):

- Learning to know: a sufficiently broad general education and the possibility of in-depth work on a selected number of subjects.

- Learning to do: learning to do a job of work and broader competences.

- Learning to live together: developing an understanding of others, respecting the values of pluralism, mutual understanding and peace.

- Learning to be: development of personality and the ability to act independently, sensibly and responsibly.

The European Union began to define lifelong learning in various documents at the end of the twentieth century (Jarvis, 2007, pp. 69-70). It was not, however, conceptualised until the publication of a document entitled $A$ memorandum on lifelong learning in 2000. In the context of the European Union, the guidelines presented in the Memorandum became the foundation for the understanding and conception of activities relating to education and learning throughout life.

The Memorandum sets out two tasks/aims for lifelong education or learning (A memorandum on lifelong learning, 2000, p. 5):

- the promotion of active citizenship (i.e. participation in all spheres of social and economic life and the extent to which people feel they belong to and have a say in the society in which they live) and

- the promotion of employability (i.e. the capacity to secure and keep employment as a condition that underpins independence, self-respect and well-being).

The guiding principle for the designers of the European concept of lifelong learning is that lifelong learning "sees all learning as a seamless continuum 'from cradle to grave"" (A memorandum on lifelong learning, 2000, $\mathrm{p}$. 8). The concept of lifelong learning can only be realised if individuals are motivated to learn. Similarly, everyone should be able to follow open learning pathways of their own choice, which means a redefinition of our understanding of education and training systems, since these should adapt to individual needs and demands rather than the other way round (A memorandum on lifelong learning, 2000, pp. 7-8). Special attention is devoted to active citizenship and professional development, i.e. employability, while the personal development and growth of the individual are not mentioned. Very broadly speaking, active citizenship could be characterised as a component that partially encourages the development of the individual's personality (Jarvis, 2007, p. 71). Nevertheless, the objective of the concept of lifelong learning as conceived by the European Union is perhaps somewhat questionable; for while the two aims mentioned may coincide and even support one another, the possibility nevertheless exists that a component or function which is pragmatic, utilitarian and interested only in economic aspects may prevail. The possibility of the reduction of aims relating to the development and personal growth of the individual is a considerable one in the present age. The efforts of countries are unfortunately oriented above all towards increasing economic growth, the economisation of society and the reduction of those segments of education that are oriented towards the formation and further development of the human being as a human being and as an individual. 
Lifelong learning should not exist merely to increase the possibility of employment and career development. It should either give relatively equal consideration to both components, or it should place greater emphasis on the development of the personality as defined by the three points of the UNESCO programme, i.e. for knowledge (general and specialist education), for respect for the values of pluralism, mutual understanding and peace, and for autonomous and responsible behaviour. A personality which develops these characteristics will also be more employable than a personality in which the focus of education and development is on employability and professional competences. Below we shall analyse the acquisition of knowledge throughout individual's life, and the importance of such knowledge, in Classical antiquity (in ancient Greece and Rome), in the Middle Ages, and in the work of J. A. Comenius, who was the first one that conceptualised the importance of learning after finished formal course of education.

\section{Analysis of Main Dimensions of Lifelong Learning in Classical Antiquity, Middle Ages, and in the Concept of J. A. Comenius}

\subsection{Ancient Greece}

In ancient Greece the understanding of education derived from two functions which can be traced back to the Archaic period, namely education as the personal, moral development of the individual and education as preparation for a career or practical work. In questions of the education and moral development of the individual, consideration of the formation or shaping of the "higher" person was present (Schwenk, 1996, p. 182). The expression they used for this, the equivalent of the phrase "upbringing and education" in modern terminology, was paideia. Over time paideia ceased to refer only to the education of children and increasingly began to be used to denote the process of development and "formation" of the individual in the broadest sense (both informative and formative and as personal growth and spiritual development), as the result of educational endeavours that last throughout an individual's life (Marrou, 1965; Schwenk, 1996). The Romans would later adopt from the Greeks this conception of the importance of education for human life, and of the aim of education.

The aim of education in the Classical period was to raise the individual to be a "complete" human being. It endeavoured to shape body and soul, emotions and intellect, character and spirit. People in the ancient world were, however, aware of the antinomy between demands for education of the body to the exclusion of all else and, on the other hand, demands for education of the spirit (Vidmar, 2009a, p. 37). A balance between these two components was never fully achieved in practice. It always remained an ideal which, however, was never renounced (Juvenalis \& Persius, 1928, p. 218).

In the Archaic, Homeric period, preparation for an occupation was the fundamental principle of education both for the common people and for the nobility, while the development and formation of moral characteristics or virtues was only "envisaged" for the nobility. The principal goal or ideal to the achievement of which an individual's entire life was directed, was areté (virtue). For Homer's heroes areté was what made a man courageous, a hero. The objective criterion by which virtue was measured was glory, which however had to be retained, not merely obtained (Vidmar, 1995, pp. 43-44).

The ancient idea disdained the technical, vocational orientation - this was a deliberate rejection, not ignorance, since both Greek and Roman education required the formation of the individual as a person who would one day be capable of doing any kind of work and exercising whatever function he (or she) chose. "Classical" education endeavoured to develop every aspect of the essence of a human being, to enable the individual to meet every demand placed on him or her by life or society, or arising as a consequence of free choice (Marrou, 1965, p. 329).

The ancient Greeks did not - or were not supposed to - learn to read and write and partake of musical and physical education in order to master a skill (téchne), in order to become experts and use that skill for gain, but in order to be enriched and shaped by the process, as Plato (1952, p. 103) defines it in his Protagoras: "For when you took your lessons from each of these it was not in the technical way, with a view to becoming a professional, but for education (paideía)." Those who worked hardest to achieve this ideal were those who had time to do so, in other words those who were not burdened by worrying about earning a living. In Ancient Greek, the "creative" free time that was devoted to education, self-improvement and moral development was called scholé, and this term could also be used to denote the place where these activities took place.

Plato was one of the first to incorporate into his concept of education the idea that learning, study and systematic development of the personality should also continue after completion of the process of education. In his vision of the ideal state he envisaged and elaborated, among other things, a precisely defined upbringing and educational path for the individual. He devoted particular attention to the highest classes of the population, i.e. the "guardians" 
and, in particular, the rulers or "philosopher-kings". He believed that the highest positions in the state should not be occupied by people who were not "able", by which he meant both the uneducated and those who had done nothing but educate themselves and therefore had no contact with reality, with practical life:

Neither could men who are uneducated and inexperienced in truth ever adequately preside over a state, nor could those who had been permitted to linger on to the end in the pursuit of culture - the one because they have no single aim and purpose in life to which all their actions, public and private, must be directed, and the others, because they will not voluntarily engage in action, believing that while still living they have been transported to the Islands of the Blest. (Plato, 1942, p. 139)

In accordance with Plato's concept of education, both boys and girls should be educated; he believes that men and women are equally entitled to perform the highest functions in the state, since the differences between them are merely physical and not intellectual (Plato, 1937, pp. 447-448). For this reason men and women should undergo the same education and training. If men are given the art of the Muses (mousiké) - a term which corresponds to "the arts and sciences" in the modern sense of the word and which also includes some elements of what later began to be designated enkýklios paideia or well-rounded education - and physical training (gymnastiké), then, as Plato says: "Then we must assign these two arts to the women also and the offices of war and employ them in the same way [as the men]" (Plato, 1937, p. 435).

Plato strongly advocates the civic virtues of political life, which should be cultivated and preserved throughout the individual's life. A properly educated individual is one whose education aims at virtue (areté) and awakens in the child the desire to become "a perfect citizen, understanding how both to rule and be ruled righteously" (Plato, 1961, p. 65). He believes that good people are almost certainly the product or result of a correct education, while as he himself says "education [paideia] [...] stands first among the finest gifts that are given to the best men" (Plato, 1961, pp. 65-67). It is also possible for a person to stray from the true path, or for education to be unsuitable. Both these circumstances can be corrected; but each individual must strive for this "so long as he lives, with all his might" (Plato, 1961, p. 67). The art of music and physical training are both intended for the development of the human personality, for personal growth (Plato, 1937, pp. 287-289).

One of the first thinkers besides Plato to ask himself whether the aim of education was the development of the personality or, rather, the preparation of the individual for work or a profession was Aristotle; whether education should be oriented towards the more realistic, towards life, as he himself says, or be more humanistically oriented, in the direction of virtue (Aristotle, 1959, p. 637), and therefore reject everything that prevents the attainment of excellence and every form of physical or intellectual specialisation:

Also it makes much difference what object one has in view in a pursuit or study; if one follows it for the sake of oneself or one's friends, or on moral grounds [areté], it is not illiberal, but the man who follows the same pursuit because of other people would often appear to be acting in a menial and servile manner (Aristotle, 1959, p. 639).

Aristotle (2004, pp. 194-196) believes that it is only possible to reach happiness, the highest possible state, or self-fulfilment when at leisure (scholé). All work and all occupations, all a man's activities must be directed towards enabling him to enjoy the highest level of life that is possible for him when he is at leisure (Aristotle, 1959, pp. 639-641); this exists in pure intellectual activity (theoria), which actually means the disinterested search for wisdom and knowledge and does not only contain study and research but also creative endeavours in the field of art and literature and the pleasure that follows consideration of the perfect and the beautiful (Curtis \& Boultwood, 1970, p. 42). Education exists simultaneously in the form of shaping (developing) the moral and the spiritual, where it is necessary to observe the following principles (Aristotle, 1959, pp. 637-639):

- Of useful things it is necessary to learn the (vitally) necessary.

- Some liberal arts and sciences can also be learnt to a certain extent.

- Nothing should be done either in theory or in practice for the sake of profit or payment, since this deprives the spirit of leisure and demeans it.

\subsection{Rome}

In keeping with their pragmatic, utilitarian philosophy, the Romans had from the earliest days placed preparation for life, i.e. an occupation, ahead of personal development (Marrou, 1965; Reble, 2004). It was not until the second century BC that Rome began to adopt Greek knowledge and the Greek concept of education, along with the related terminology. Thus it was that the Romans translated enkýklios paideia as artes liberales, or "liberal arts"; the first to use this expression in the sense of a programme of general education was M. T. Cicero (for more on this see Vidmar, 2009b). 
The celebrated orator and rhetorician M. F. Quintilian was the first Roman to mention the importance of non-formal education and learning when he stated that "free time" was just as important for the formation of a young man as the hours spent at school in the company of a paedagogus (Quintilianus, 1922, pp. 7-21). At school, "where there are many pupils, a youth will not only learn what is taught to himself, he will learn what is taught others as well. He will hear many merits praised and many faults corrected" (Quintilianus, 1922, p. 21). Quintilian identified the artes characteristic of general education of the secondary level with the Greek paideia, finally defining the meaning of enkýklios as "rounded", and called them "orbis doctrinae":

I will now proceed briefly to discuss the remaining arts in which I think boys ought to be instructed before being handed over to the teacher of rhetoric, for it is by such studies that the circle of education [orbis doctrinae]

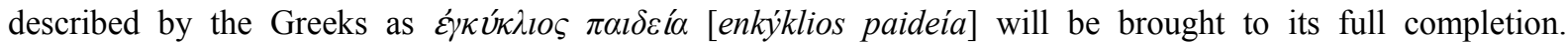
(Quintilianus, 1922, p. 56)

He understood them as the content of those disciplines that are combined in the circle or whole of general, common education, in the sense that they serve no vocational purpose but as "pure" disciplines enable "applied" science and are the basis for the highest science - i.e. rhetoric.

\subsection{The Middle Ages}

One of the characteristics of the Middle Ages was the division of society into three classes, estates or orders (ordines), within the framework of which each of these social groups had its own internal structure and was strictly limited in its relationship to the next group (Duby, 1985; Riché, 1979). The individual order was the centre of specific views and customs, and also of social institutions and institutions of education, which gave a unique character both to clerical education and to the education imparted to the noble or commoner classes. Each of the three estates typically had its own organisation of education or training, which derived from the needs ascribed to the order/estate. We can only really talk about education in the modern sense of the word in the case of education within the order of the clergy. Both the clergy - in particular monks - and the nobility provided, in a specific way, either at the formal level or informally, something that would be defined today as a form of lifelong education/learning.

Education within the order of "those who pray" (oratores), i.e. the clergy, was devoted above all to satisfying vocational needs, while at the same time it also represented the acquisition of a general education (the Greek enkýklios paideia or the Latin artes liberales). After completion of the envisaged schooling it is possible to identify, particularly in the case of members of monastic orders, a desire for education or learning to continue. There is also an evident change in the function of learning or education, in that its role should be above all that of personal development and no longer professional development. The foundations for this began to be established in the fifth and sixth centuries, when the founders of monastic orders in Western Europe called for the daily reading of various texts.

The Rule of St Pachomius written in the fourth century by the founder of cenobitic monasticism, says that an illiterate candidate wishing to enter the monastery should spend three hours a day being taught to read by an older, educated monk:

Whoever enters the monastery uninstructed [rudis] shall be taught first what he shall observe. And if he is illiterate he shall go to the teacher so delegated and learn with the greatest of eagerness and gratitude. Even if unwilling, he shall be compelled to read! No one whosoever shall be in the monastery who does not learn to read [discat litteras]. (Pachomius, 1846, Col. 291-292)

With St Benedict of Nursia, the founder of the Benedictine order, the above requirement that monks should devote themselves everyday to reading, which actually means that they should learn (and in this way see to their own «personal development»), reaches its apogee. The Rule of St Benedict envisages reading, i.e. learning, as one of the foundations of the monastic life: "Idleness is the enemy of the soul. Therefore, the brothers should have specified periods for manual labour as well as for prayerful reading" (Benedictus, 1847, Col. 703A). At that time the same rules that applied to monks also applied to nuns (Arelatensis, 1865, Col. 1109C-D). Centuries later Abbot Smaragdus was of a similar opinion and taught that reading (i.e. learning, education) was what helped a person develop his or her own self:

All progress is the result of reading [lectio] and reflection [meditatio]. Reading the Holy Scriptures is a twofold gift. It educates the understanding of the mind [intellectum mentis]. In a certain way the Bible grows with its readers. Unlearned readers [rudes lectores] come to know it, while the learned [docti] constantly discover it anew. (Smaragdus, 1851, Col. 597C-598A) 
The sons of the nobility, the order of "those who make war" (bellatores) were rarely sent to school if they were able-bodied and suitable for a military career. One of the reasons for this is the fact that from their earliest youth these children had to be educated and trained in a manner entirely different from that which was customary in existing schools (which were organised and conducted by the clergy) (Odo, 1853, Col. 645A). During their training these youths frequently tested their strength and knowledge against those of their peers. During the course of his "education" or training, a young nobleman had to complete three stages (Good \& Teller, 1969; Müller-Freienfels, 1932; Specht, 1895):

- the page (roughly seven years old; he learned to serve the table, hunt game and play chess);

- the squire (roughly 14 years old; care of a knight's weapons and horse, continuation of training in the skills of a page);

- the knight (roughly 20 years old; the young man becomes a knight in a special ceremony and receives a sword and spurs, the symbols of knightly rank).

The members of the order of "those who make war", i.e. the nobility, the knights, were required to train constantly in order to maintain their condition and their skill at handling their weapons. They did this right up until old age, or for as long as they were capable.

In the Middle Ages the daughters of noble families for the most part acquired essential knowledge at home, where they were taught by tutors. Although knowledge of Latin was still important, their attention increasingly began to be drawn by love songs and chivalric romances in vernacular languages. A typical example of the education of a noblewoman can be found in Tristan by Gottfried von Strassburg, where the author describes the education of Isolde. As a child she began to be educated by the family chaplain in reading, writing, French and Latin; the court minstrel taught her courteous behaviour, the harp, singing, letter-writing and the writing of chansons (Specht, 1895; Strassburg, 1873, Col. 7965-8145).

Even within the order of "those who work", i.e. ordinary working people or commoners, there were differences between the individual subgroups into which this order was divided. Generally speaking peasants had the lowest status. In the case of the peasant population, education in the broadest sense of the word was limited to two functions: practical preparation for life, which was the responsibility of parents or guardians; and the moral formation of individuals, which was the responsibility of the clergy (Limmer, 1928; Riché, 1979). For a long time the fear of idolatry meant that there were no statues in churches. Over time, however, the Church began to accept painted and carved images, which were also known as the Poor man's Bible or "mute sermon". Their purpose was to help the simple faithful better understand biblical themes (Dhondt, 1968; Grundmann, 1958; Riché, 1979; Specht, 1895). All clerics, who knew the importance of rhetoric, saw the sermon as the most effective means of recruiting people to the Christian cause. Sermons in the vernacular have for the most part not been preserved; in their instructions to priests regarding preaching, bishops ordered that those priests who "knew" the Bible should explain it, while the others should persuade the people to reject evil, do good and strive for peace (Riché, 1979, pp. 323-324).

\subsection{The Reformation}

By calling for the establishing of individualised contact with God and the reading of the Bible by the faithful themselves in their own mother tongues, the Reformation established a new paradigm for the understanding of learning throughout life which also implies specific components of the modern concept of lifelong education/learning. German Protestant teachers devoted most of their attention to the secondary level of education while also giving some regard to the tertiary level, above all because of the great shortage of educated people, i.e. teachers and clergy, and involved themselves very little or hardly at all with teaching literacy and other forms of adult education and learning.

Martin Luther, the father and leading representative of the Reformation, realised relatively early on that in order to spread the faith and preserve the various ecclesiastical and secular professions a reorganisation of schooling and education in general was urgently necessary. He believed that upbringing and education were a matter for the three fundamental institutions of society, namely family, school and church, each of which had its own mission and its own tasks, duties and rights (Bertin, 1961; Roth, 1898). Luther publicly intervened in the field of education with his own authority when it became clear that despite all the good intentions and the possibilities of individualisation of religion, people would not of their own impulse enable the education of their children and send them to school, while at the same time nobody would voluntarily maintain schools.

In 1520, in an open letter to the German nobility entitled To the Christian nobility of the German nation concerning the reform of the Christian estate, Luther expressed the desire that boys and girls should study the 
Bible for at least one hour every day (Luther, 1520/1975). Four years later, in 1524, he wrote a circular entitled To the councilmen of all cities in Germany that they establish and maintain Christian schools, in which he places the responsibility for schooling and education in the broadest sense on the civic authorities (Luther, 1524/1975). One of the most important tasks of the secular authorities should be that wherever possible they establish schools for boys and girls in which they can be educated for an hour or two each day. Luther believes that unfortunately most parents are unfitted for this work and do not know how to train and teach their children themselves. On the other hand, even if parents were able and willing to teach their children themselves, they have neither the time nor the opportunity for it, what with their other duties and housework. Luther believes that

the training which is undertaken at home, apart from such schools, attempts to make us wise through our own experience; before that comes to pass we shall be dead a hundred times over; for much time is needed to acquire one's own experience. (Luther, 1524/1975, p. 172-174)

\section{Conceptualization of Lifelong Learning by J. A. Comenius}

One of the most important and essential demands of the Reformation, as we have shown, was the individualized communication of the faithful with God, and with it came a tightly connected demand of reading the Bible in the mother tongue of the faithful themselves. These two demands were oriented toward youth as well as adults, who should, for their fulfillment, acquire at least a basic knowledge of reading (and writing).

Comenius took all his definitions and concepts from the conviction that the broadest masses of people should be educated, regardless of social class, age or sex. He summarized his philosophical, religious and pedagogical principles in a collection of papers with the title General consultation of the improvement of human things (De rerum humanarum emendatione consultatio catholica), parts of which remained unknown until 1935 and which was first published in 1966. This work has two central theses, in which Comenius presents his vision of the regulation of the world: Pansophia (Universal wisdom) and Pampaedia (Universal education), where Comenius presented his views on education as a continuous cycle, which lasts and should last from birth till death (Comenius, 1966). It was important for him to emphasize the voluntariness of education, particularly after the course of formal schooling is completed, and this is one of the essential postulates of the contemporary theory of lifelong learning. Several times, he also emphasized that human life itself is a school, divided into parts, which correspond to the periods of life (Comenius, 1966). Each of them has its own specific curriculum, demands, and objectives.

Comenius was one of the most idealistic and optimistic great persons in history, who lived to the last in hope that the world could be made better. His works are imbued with faith in the power of common sense and human goodness. One of the essential points of his doctrine is education, since ignorance is the greatest evil, which carries misery and misfortune to the people; he is on the other hand also convinced that acquiring of knowledge and erudition is not enough, that moral formation is needed to make people good and merciful.

The concept of lifelong learning, which Comenius conceived, consisted of three vital points (of learning): all (omnes), in everything (omnia), wholly (omnino) (Comenius, 1966, Caput I, Col. 7; Caput II, Col. 15). Each one should be formed in good manners and humanity (Comenius, 1966, Caput II, Col. 40). Comenius above all demanded the formation of a human as a human (Comenius, 1966, Caput II, Col. 30-31).

Pampaedia is, according to Comenius, "universal culture (cultura universalis) of the entire human race" (Comenius, 1966, Caput I, Col. 4). He expressed the need to develop, i.e., to educate each human being into a human and promote his/her harmonic physical and intellectual development, which is nowadays one of the most important demands of lifelong learning. Next, Comenius emphasized, and this too can undoubtedly be placed in the contemporary concept of lifelong learning, the demand for acquiring knowledge of all things that comprise human nature: a human should know what is true and should not be deceived by the false; he should love good things and not be seduced by evil; he should do what needs to be done and not allow that which one should run away from; when necessary, he should talk to all others wisely and not remain silent; he should everything do rationally (Comenius, 1966, Caput I, Col. 5).

Comenius demanded learning for all people, regardless of age, social class, sex or nationality (Comenius, 1966, Caput I, Col. 4-6). In the context of education and learning Comenius rejected any discrimination against physically or mentally handicapped persons and therefore, he is one of few who already in the 17th century recognized and demanded rights for disabled persons: "Anyone who participates in a human nature must in the same extent participate in the education (cultura); moreover, those who are anyhow deprived, physically or mentally, should be taken particularly good care for" (Comenius, 1966, Caput II, Col. 19-20). 
His concept of education consisted of an indispensable course of formal education, which should last approximately until the twenty-fifth year of life, as well as of non-formal and informal learning, if we use modern terms: "For each individual, his entire life is a school, from the cradle until the grave. Each period of life is intended to learning and we humans have not other objectives for living as for learning" (Comenius, 1966, Caput V, Col. 54).

Comenius divided human life into seven periods, and for each period he foresaw one so-called school - he defined even the eighth school, the school of death (schola mortis), but he did not elaborate its contents, which are entirely transcendent. Non-formal and informal methods of learning he primarily foresaw for the last two schools, although even before, in the first four schools, he elaborated in detail different ways, methods and means of learning, which also include the above-mentioned approaches (Comenius, 1966, Caput XII; Caput XIV). Adulthood is a central part of life for Comenius, a period of the greatest prosperity, because the primary objective of all earlier periods is to come here (Comenius, 1966, Caput XII, Col. 197).

The school of adulthood is more liberal than earlier ones, because it is not so tightly connected with particular, obligatory books and teachers; every occupation is in a way some kind of a school for the individual. That is, why everyone is his own teacher and his own textbook and school. Everyone should be taught by his own examples and teachings (praecepta) and should take care of permanent practice. Very important in this school is the help of friends and surroundings (Comenius, 1966, Caput XIII, Col. 199). For Comenius, there was almost no book in which someone could not find anything good at all (Comenius, 1966, Caput XIII, Col. 200-201).

According to Comenius, learning should continue even during the last period of human life, old age. For work with the aged, special methods and modes of treatment are needed (Comenius, 1966, Caput XIV, Col. 219-220). The primary objective of the school of aged persons is a good conclusion of this-side life and a proper preparation for entering the eternal life. In this school should be taught and learned how aged people can, know and will correctly enjoy what they have created; how to spend the remainder of their lives appropriately (Comenius, 1966, Caput XIV, Col. 221). Even this school has its own methods and modes for work, such as examples, precepts, admonitions, and experience. Aged people have many experiences, which should be transmitted into the future, to next generations (Comenius, 1966, Caput XIV, Col. 223). Aged people must also learn to consider their past life, which means to rejoice in what they have done well and to think how to correct deeds, which were not good (Comenius, 1966, Caput XIV, Col. 224).

\section{Conclusion}

It was not until the twentieth century that adult learning began to be the object of more widespread and in-depth consideration on the part of theoreticians and practitioners of education. In past periods the acquisition of knowledge and understanding in adults was, for the most part, an issue that regarded those who had already completed formal education, and was less connected to the question of basic literacy. Even so, it is possible to identify individual components of lifelong learning in every period of history. In ancient Greece moral education was pre-eminent. The Greeks did not strive to educate and form writers, artists, scholars, but human beings, individuals who conformed to a prescribed norm. The Classical Greek concept regarded above all the human being as such, not the technician or expert trained for a specific yet partial function. The aim was to educate or form an individual who would be able, if and when this was necessary, to acquire specific specialist knowledge. In some periods one component or function would predominate; in others it would be the turn of another. The importance of the development of the individual's personality, as it is today understood by the theory of lifelong learning, was particularly emphasised by Plato and Aristotle, who actually shaped the Classical concept and ideal of upbringing and education and its subsequent development in the Hellenistic period.

In the Middle Ages the driving force behind education in the broadest sense of the world was above all religious. Influential church thinkers required monks and other clergy to read the Bible and other «holy books» as part of the development of the personality of the individual, while the strengthening of piety was above all left to prayer. One of the characteristics of this period was the tripartite division of society, where separate rules of education and training applied to each of the classes or estates. It would be difficult to talk about a single model, since they differed both in their aims and in the methods and means they employed. Within the clerical estate, education combined professional development (in the sense of preparation for a career) with the personal development of the individual - or spiritual development as it would have been called in the Middle Ages. Here we note the alternation and complementarity of both functions of the modern understanding of lifelong education and learning, including in its non-formal and informal guises. Of the noble estate we may say that modern notions of lifelong learning can be identified in the form of uninterrupted training in military and athletic skills, which was a condition for the successful practice of the "profession" of knight. If we consider modern conceptions of 
lifelong learning in the broadest possible sense, then we can also include the estate of commoners - i.e. peasants - in the sense of the development of personality. Sermons on Sundays and other feasts days meant that peasants received regular moral instruction from the clergy.

Protestantism brought with it the requirement for the faithful to read the Bible and other (suitable) books throughout their lives. The reasons given for this included the formation or development of the individual's personality. We can agree without hesitation that this was essentially the same justification that was given in the Middle Ages. We could, however, point out, as a significant difference between the medieval and Protestant notions of the development of the personality of the individual, that with Protestantism the demand for reading is democratised and transferred from the narrow group of the holy - i.e. the clergy - to all people, in other words to all classes of the population. At the same time the language of education and literature also changes: it is no longer only Latin but the mother tongue of the readers or those who are being educated. Essentially we can say that the Reformation and the principle of the democratisation of education (not least with regard to the methods and forms of its provision) marked the start of a process that reached one of its peaks in the second half of the seventeenth century with Comenius and his concept of learning throughout life, and another in contemporary concepts and understandings of lifelong education and learning in all its various forms. With Comenius we can see the transition from the elements of deliberation to a whole system. He was the first one who clearly defined a process of permanent or lifelong learning and education with all of its demands. These demands correspond to a great extent (in some points totally) to definitions which are found in contemporary conceptualizations of lifelong learning. In his concept of learning throughout life Comenius demanded that the cycle of education should not end after a formal course of schooling is concluded, but should continue even afterwards, until death. He elaborated a detailed plan and program of such education or learning, which is flexible enough to be adjusted to the individual needs of a person. An important contribution to the modern understanding of the objectives of learning was his demand for equal and harmonic development of the whole personality, of the body and the soul. Although Comenius preferred a preparation for practical action in life, that is preparation for occupation as the objective of education during a course of formal schooling, for him the most important objective was the development and formation of the human as a Human. Human personality should be developed because of itself, an individual to be more human and good, not only to be a "travelling encyclopedia" or to master a certain occupation. On the base of his understanding, we can with certainty say that already in the 17 th century he enabled the definition of lifelong learning. His concept was afterwards almost lost and forgotten, and unfortunately nowadays we see that even modern theories of lifelong learning mostly forget about Comenius, and it therefore is made to appear that, before modern conceptualization, there was no single theory at all which would define it.

\section{References}

A Memorandum on lifelong learning. (2000). Brussels: Commission of the European Communities.

Arelatensis, C. (1865). Regula ad virgines. In J. -P. Migne (Ed.), Patrologiae latinae cursus completus (Vol. 67, Col. 1105-1121). Paris: Migne.

Aristotle. (1959). Politics (Loeb Classical Library, Vol. 264). Cambridge, MA \& London: Harvard University Press \& William Heinemann.

Aristotle. (2004). Nicomachean ethics. Cambridge: Cambridge University Press.

Benedictus. (1847). Regula. In J. -P. Migne (Ed.), Patrologiae latinae cursus completus (Vol. 66, Col. 215-293). Paris: Migne.

Bertin, G. M. (1961). La pedagogia umanistica europea nei secoli XV e XVI. Milano: Marzorati.

Comenius, J. A. (1966). Pampaedia. In De rerum humanarum emendatione consultatio catholica. Pragae: Academia scientiarum Bohemoslovaca.

Curtis, S. J., \& Boultwood, M. E. A. (1970). A short history of educational ideas. London: University Tutorial Press.

Delors, J. (1996). Learning, the treasure within: Report to UNESCO of the international commission on education for the twenty-first century. Paris: Unesco.

Dhondt, J. (1968). Fischer weltgeschichte: Das frühe mittelalter. Frankfurt am Main: Fischer Bücherei.

Duby, G. (1985). Studia humanitatis: Trije redi ali imaginarij fevdalizma. Ljubljana: ŠKUC in Filozofska fakulteta. 
Establishing an integrated action programme in the field of lifelong learning: Decision of the European parliament and of the council. (2004). Brussels: Commission of the European Communities.

Good, H. G., \& Teller, J. D. (1969). A history of western education. London: The Macmillan Company.

Grundmann, H. (1958). Litteratus - illitteratus: Der wandel einer bildungsnorm vom altertum zum mittelalter. Archiv für Kulturgeschichte, 40, 1-65. http://dx.doi.org/10.7788/akg-1958-jg02

Jarvis, P. (2007). Lifelong learning and the learning society: Globalisation, lifelong learning and the learning society. Sociological perspectives. London, New York, NY: Routledge.

Juvenalis, D. J., \& Persius, A. F. (1928). Juvenal and Persius. London, New York, NY: William Heinemann, G. P. Putnam's Sons.

Limmer, R. (1928). Bildungszustände und bildungsideen des 13. jahrhunderts. München \& Berlin: R. Oldenbourg.

Luther, M. (1975). An den christlichen Adel deutscher Nation von des christlichen standes besserung. In Hutten, Müntzer, Luther. Werke in zwei bänden (Vol. 2, pp. 15-99). Berlin \& Weimar: Aufbau-Verlag.

Luther, M. (1975). An die ratsherrn aller städte deutsches lands, daß sie christliche schulen aufrichten und halten sollen. In Hutten, Müntzer, Luther. Werke in zwei Bänden (Vol. 2, pp. 152-182). Berlin \& Weimar: Aufbau-Verlag.

Marrou, H. -I. (1965). Histoire de l'éducation dans l'antiquité. Paris: Éditions du Seuil.

Müller-Freienfels, R. (1932). Wissenschaft und bildung: Bildungs- und erziehungsgeschichte vom mittelalter bis zum ausgang der aufklärung. Leipzig: Quelle \& Meyer.

Odo. (1853). De vita sancti Geraldi Auriliacensis comitis. In J. -P. Migne (Ed.), Patrologiae latinae cursus completus (Vol. 133, Col. 639-704). Paris: Migne.

Pachomius. (1846). Regula ad monachos. In J. -P. Migne (Ed.), Patrologiae latinae cursus completus (Vol. 50, Col. 271-302). Paris: Migne.

Plato (1952). Protagoras (Loeb Classical Library, Vol. 165). Cambridge, MA \& London: Harvard University Press \& William Heinemann.

Plato. (1937). The Republic I (Loeb Classical Library, Vol. 237). Cambridge, MA \& London: Harvard University Press \& William Heinemann.

Plato. (1942). The Republic II (Loeb Classical Library, Vol. 276). Cambridge, MA \& London: Harvard University Press \& William Heinemann.

Plato. (1961). Laws I (Loeb Classical Library, Vol. 187). Cambridge, MA \& London: Harvard University Press \& William Heinemann.

Policy brief: Lifelong learning. (2001). Paris: OECD.

Quintilianus, M. F. (1922). Institutionis oratoriae libri duodecim (Vol. 2). Leipzig: Teubner.

Reble, A. (2004). Geschichte der Pädagogik. Stuttgart: Klett-Cotta.

Riché, P. (1979). Les écoles et l'enseignement dans l'occident chrétien: De la fin du ve siècle au milieu du xie siècle. Paris: Éditions Aubier-Montaigne.

Roth, F. (1898). Der einfluss des humanismus und der reformation auf das gleichzeitige erziehungs-und schulwesen bis in die ersten jahrzehnte nach Melanchthons tod. Halle: Verein für Reformationsgeschichte.

Schwenk, B. (1996). Geschichte der bildung und erziehung von der antike bis zum mittelalter. Weinheim: Deutscher Studien Verlag.

Smaragdus. (1851). Diadema monachorum. In J. -P. Migne (Ed.), Patrologiae latinae cursus completus (Vol. 102, Col. 593-690). Paris: Migne.

Smith, M. K. (2001). Lifelong learning. Retrieved from http://www.infed.org/lifelonglearning/b-life.htm

Specht, F. A. (1895). Geschichte des unterrichtswesens in Deutschland von den ältesten zeiten bis zur mitte des dreizehnten jahrhunderts. Stuttgart: L. C. Cotta'schen Buchhandlung.

Strassburg, G. V. (1873). Deutsche classiker des mittelalters: Tristan (Vol. 1). Leipzig: F. A. Brockhaus.

Vidmar, T. (1995). Razmerje med vzgojno in izobraževalno funkcijo pouka od Homerja do sredine 13. stoletja. Sodobna pedagogika, 46(1-2), 43-52. 
Vidmar, T. (2009a). Position of the medieval school in the context of political relations. In A. Kozłowska, \& J. Muršak (Eds.), Poland, Slovenia, the world. Challenges of present-day education (pp. 277-287). Krakow: Krakow Society for Education.

Vidmar, T. (2009b). Vzgoja in izobraževanje $v$ antiki in srednjem veku. Ljubljana: Znanstvena založba Filozofske fakultete Univerze v Ljubljani.

Watterston, J. (2006). Learning that lasts: Lifelong learning and the knowledge. Retrieved from http://www.icponline.org/index.php?option=com_content\&task=view\&id=102\&date=2008-01-01

\section{Copyrights}

Copyright for this article is retained by the author(s), with first publication rights granted to the journal.

This is an open-access article distributed under the terms and conditions of the Creative Commons Attribution license (http://creativecommons.org/licenses/by/3.0/). 